\title{
磁気共鳴を用いた生体レドックスイメージング（ReMI）
}

\author{
内海 英雄
}

\section{Novel Redox Molecular Imaging “ReMI” with Dual Magnetic Resonance}

\author{
Hideo Utsumi \\ Innovation Center for Medical Redox Navigation, Kyushu University; \\ 3-1-1 Maidashi, Higashi-ku, Fukuoka 812-8582, Japan.
}

(Received April 3, 2013)

\begin{abstract}
Free radicals, reactive oxygen species (ROS), and redox status are known to be involved in cell signaling, proteomics, etc. in homeostasis and oxidative disease. Electron spin resonance (ESR) spectroscopy is a very sensitive and selective technique for detecting free radicals, and we have developed an in vivo ESR spectroscopy/imaging system combined with a nitroxyl probe for noninvasive assessment of free radical reactions in various disease models such as diabetes, cancer, liver/lung damage, gastric lesions, brain injury, etc. The systematic measurement with probes having different degrees of membrane permeability make it possible to clarify the location of free radical generation in blood vessels, cell membranes, and the cytoplasm. Our findings strongly indicate the great advantage of the in vivo ESR spectroscopy/imaging/nitroxyl probe technique in biomedical sciences. However, the spatial resolution of the ESR spectroscopy imaging system is insufficient due to the short $\mathrm{T}_{2}$ of probes. Proton magnetic resonance imaging (MRI) has significant clinical utility in the diagnosis of disease. Dynamic nuclear polarization (DNP) -MRI yields highly resolved images of free radical distribution in small animals by enhancing the water proton signal intensity via the Overhauser effect. We developed a new sequence for DNP-MRI and succeeded in obtaining simultaneous dual images using radicals labeled with ${ }^{14} \mathrm{~N}$ and ${ }^{15} \mathrm{~N}$ nuclei. This technique can visualize individual redox processes and the individual redox status of inner and/or outer cells in a dose-dependent manner. More recently, we have developed a novel DNP-MRI scanner and enables the use of DNP-MRI in different disease models.
\end{abstract}

Key words_— reactive oxygen species; redox; magnetic resonance imaging; electron spin resonance; free radicals; oxidative disease

\section{1.はじめに}

卒業研究（東京大学薬学部）で「薬品製造工学」 を選んだことが電子スピン共鳴（electron spin resonance; ESR）との出会いである. 管教授の指示で当 時博士課程 2 年生の桐野 豊さん（現徳島文理大学 学長）の指導を受けることとなった。桐野さんはア スコルビン酸（ビタミンC）の酸化中間体を ESR フロー法で研究しており, 私のテーマは「アスコル ビン酸とヒドラジンの反応中間体ラジカルの構造解 析」であった。種々のアスコルビン酸誘導体を合成 し，ヒドラジン類との反応中間体の構造解析をして 修士論文とした。

The author declares no conflict of interest.

九州大学先端融合医療レドックスナビ研究拠点（†812

-8582 福岡市東区馬出 3-1-1)

e-mail: hideo.utsumi.278@m.kyushu-u.ac.jp

本総説は, 平成 24 年度日本薬学会賞の受賞を記念して 記述したものである.
博士課程進学時に自分自身で研究テーマを探すこ とになり生物関係に興味を覚え「スピンラベル法に よる膜脂質の動的構造に関する研究」とした。一人 で，スピンラベル脂肪酸の合成，卵黄レシチンの抽 出・精製，スピンラベル化リポソームの作製と ESR 測定を行った。幸い，国立予防衛生研究所か ら野島庄七先生が薬学部教授に赴任することとな り, 井上圭三先生からリポソームの指導を受け, 博 士論文「スピンラベル法による膜脂質の動的構造に 関する研究」をまとめた。

学位取得後, 野島研で膜脂質の流動性と抗原性に ついて研究し, 1978 年から 2 年間, ドイツのケル ン大学医学部 Stoffel 教授の下で ${ }^{13} \mathrm{C}-\mathrm{NMR}$ を用いた 膜タンパク質・脂質相互作用の研究を行い, NMR への親近感ができるとともに生命現象への関心が一 層深くなった.

1982 年に昭和大学薬学部衛生化学教室の助教授 
として赴任した。ESR やNMRによる膜流動性の 研究を継続していたが，1986 年にたまたま，日本 電子の藤本氏から生体計測 ESR の報告例を聞き, 瞬間的に「面白い」と思い，直ちに大学院生と一緒 に装置開発に着手した。また，濱田教授のご支援 で，私学助成「大型設備導入」で生体 ESR 画像解 析装置が採択され，翌 1987 年に日本電子に共同開 発を依頼した。多くの困難な事柄があったが，幸い 完成し，マウスで ESR 測定と画像化研究を始め た。また，ラット用装置が必要となり，300 MHz ESR 装置の開発に着手した。日本電子の会社近く のとんかつ屋に OHP を持ち込み，技術者諸氏と熱 く打ち合わせをし，ヒトの腕も入るループギャップ 型共振器と装置が完成した.

1994 年に九州大学へ赴任した際, マウス用, ラ ット用 ESR 装置などの研究設備を昭和大学の厚意 で九州大学に寄贈して頂き, 病態モデル動物への応 用を中心に研究を進めた，新規プローブ剂を合成す ることで，多くの疾患モデルでレドックスと病態発 現の関係が明らかとなった。また，解剖学情報を 付加するため, ESRI/magnetic resonance imaging （MRI）融像可視化装置を開発した. 2003 年には Philips 社が試作したオーバーハウザー効果を利用 した dynamic nuclear polarization (DNP)-MRI に新 たな解析アルゴリズム法を提案・導入するとともに 機能性ニトロキシルプローブの開発，病態モデルへ の応用研究を行った。しかし，Philips 社の R\&D 装
置は感度が低いことから，2004 年から 5 年かけて 独科学技術振興機構 (Japan Science and Technology Agency；JST）の先端計測機器開発事業の支援の 下，高感度の DNP-MRI を試作した.

これらの成果が出始めた 2008 年に, 科学技術振 興調整費の先端融合領域イノベーション推進事業に 応募することとなり，薬学が中心となり医学，農 学, 工学が加わりプロジェクト提案した結果, 「先 端融合医療レドックスナビ研究拠点」が採択され た。この拠点は 10 年間の大型プロジェクトで, 産 学連携して新たな研究領域をイノベーションし研究 結果を製品として社会還元することが求められてい る. 特許の関係で，本稿で記述できないが，全く新 しい概念のレドックス画像化システム“ReMI”に 向けたシーズが蓄積しつつある.

\section{In vivo 用 ESR 画像化装置の開発研究}

最も馴染みのある UV 吸収分析から明らかなよう に，ほとんぞの分析法は電磁波を試料に照射し変化 を検出する. Figure 1 に電磁波の波長と検出に適し た試料の大きさの関係を示すように，電磁波の中で 波長が短い光は生体への浸透性が低い. 電子スピン 共鳴で用いる電磁波も，水など誘電率の高い試料で は電磁波の電界成分と双極子相互作用することで誘 電損失が起こり，試料は発熱（電子レンジの原理） し生体浸透性（skin depth と呼ぶ）も低くなる。 そ こで，生体計測では，(1)浸透性の高い低周波電磁波 （1 GHz で $2 \mathrm{~cm}, 100 \mathrm{MHz}$ で $20 \mathrm{~cm}$ 程度）と, (2)

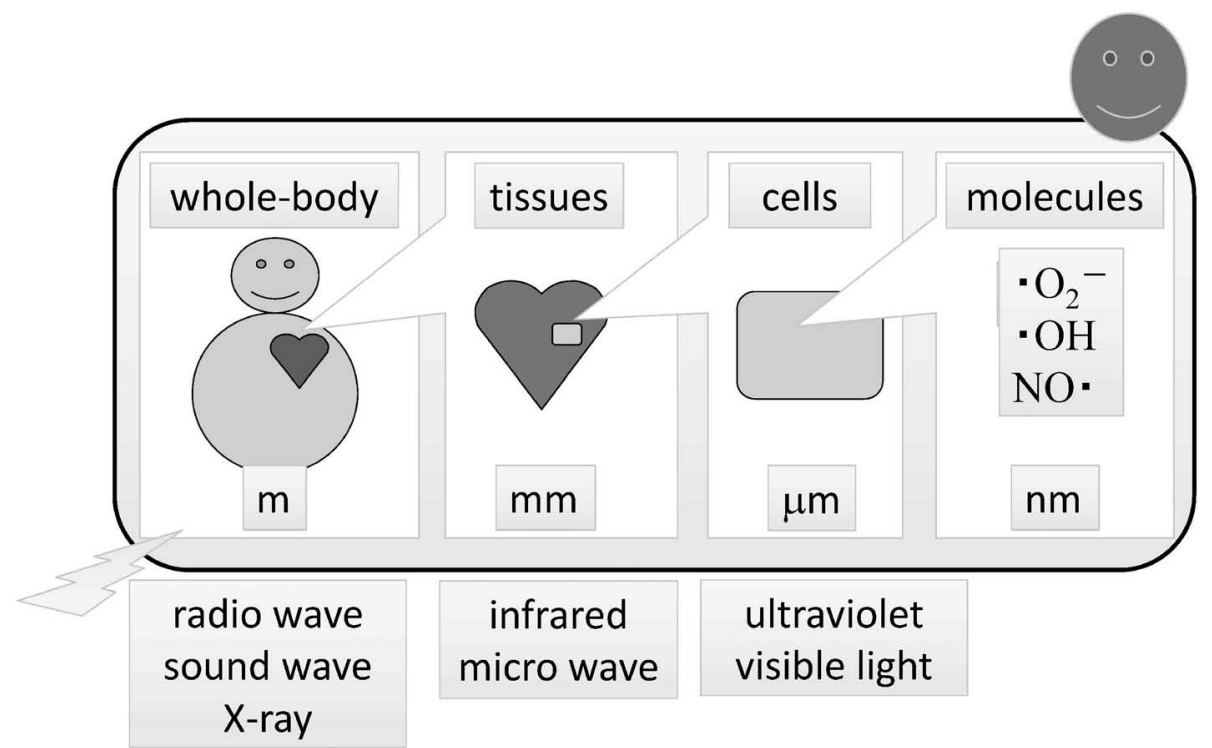

Fig. 1. Relation between Electromagnetic Wave Length and Skin Penetration 
電磁波の電界成分と試料との接触を抑える検出法 （ループギャップ型，リ・エントラント型共振器や 電界分離サーフェイスコイルなど)を用いることで, 1985-86 年に数カ所の研究所で生体計測 ESR の開 発に成功していた。

筆者らも 1987 年に日本電子とともに装置開発を 開始し，小野らが開発したシールド型ループギャッ プ共振器をべースに動物用横型と摘出臓器用縦型 （温度調節可能）共振器を作製した。動物の放尿な ぞにも配慮し試料部は密閉型で, 縦型共振器では温 度可変できる. 当時は, $1 \mathrm{GHz}$ 発信機などの部品 が軍需規制品に該当し，購入に苦労したと聞く，画 像化に関しては日本電子に技術がなかったため，磁 場勾配コイルや画像化のアルゴリズムソフト開発か ら着手した。磁場勾配下では通常の ESR スペクト ルに位置情報が重畳(畳み込み)されて観測される. したがって，位置情報を得るには重畳スペクトルか ら通常スペクトル情報を除く逆重畳が必要で，逆重 畳はフーリエ面で除算する方法が一般的である。こ の磁場勾配の向きを回転させ，各方向での一次元情 報を得た後，逆投影することで 2 次元あるいは 3 次 元の画像を作成する. この逆投影法では投影方向に 星型のノイズが生じるので，ノイズ消去用フィル ターを一次元情報に畳夕込む方法が有効で，この演 算にもフーリエ級数が有用とされていた。早速，磁 場勾配コイルの自作に取り掛かり，失敗の連続であ つたが，最終的に Fig. 2 (a)に示す磁場勾配コイル が完成した。 また，フーリエ変換ソフトが市販され ていなかったため，バタフライ法を利用し，逆投影 法を自作した。デー夕取得は 16 bit の AD コンバー
ターを介して，磁場勾配制御は定電流電源をコンピ ユータ制御し行った。

この間，何度も日本電子（昭島）で打ち合わせを 行い, 西川先生や尾形先生の研究室に伺いご教示頂 いた。これらの先行研究を基にして，1989 年に Lband ESR 装置が完成し昭和大学に導入されたが, 導入直後の装置は共振器の結合調整が難しく, 水溶 液中のラジカルは検出できるが生理食塩水や動物中 のラジカルは全く検出できなかった．当時の大学院 生による血の滲むような試行錯誤を経て，マウスに 尾静脈内投与したニトロキシルラジカルのシグナル

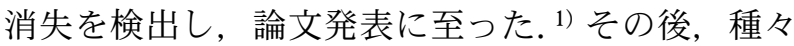
の改良を加えることで，20-30 g のマウス腹部など 生体計測が可能となり高酸素暴露や食餌とレドック ス代謝の関係が明らかになった。 ${ }^{2,3)}$ また，画像化ソ フトを徳島在住の芝氏に外注し，生体計測 ESRI 装 置が完成した。二次元画像の一例を Fig. 2(b) に示 す。ニトロキシルラジカルの生理食塩溶液をマウス 気管内に強制投与し胸部を画像化したもので，肺の 形と一致し心臓部が欠けた画像を得た. ${ }^{4)}$ ちなみに,

Fig. 3 は昭和大学の装置をカタログ用に撮影したも ので，本装置は，大学や研究機関などに 20-30 台程 が導入されている.

医薬品の薬効評価には病態モデルラットが汎用さ れている，既に，日本電子とは多くの共同開発を手 掛けていたことから，より大きいラット用 300 MHz ESR 装置 [Fig. 4(a)］とヒトの腕も入る内径 $65 \mathrm{~mm}$ のループギャップ型共振器 [Fig. 4(b) ] が 完成した。本装置は糖尿病モデルラットの解析に威 力を発揮し, 九州大学赴任後初めての臨床医学者と (a)

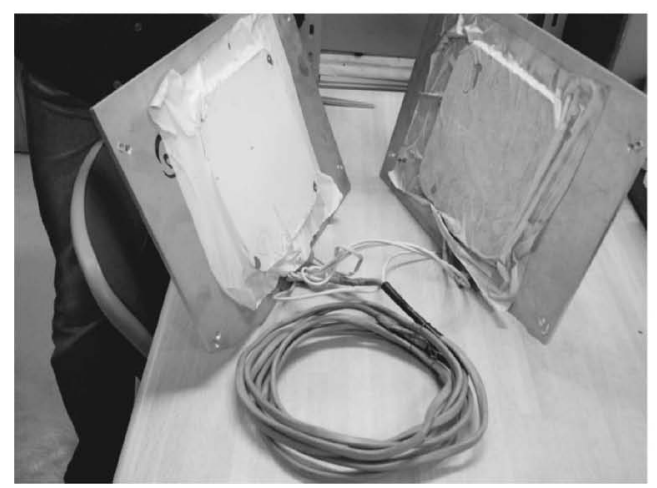

(b)

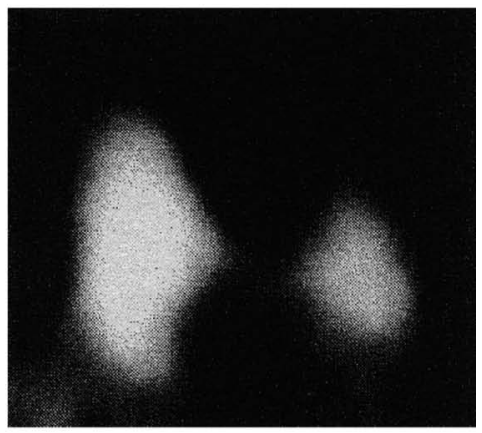

Fig. 2. Home-made Field Gradient Coils (a) and ESRI Image of Mouse Lung after Tracheal Injection of Nitroxyl Radical (b) 
の共同研究に発展した. ${ }^{5)}$

一方, 生体内では複数のラジカルが存在していた り，異なる運動状態に由来し複数のスペクトルが観 測されることが多い. 複数種のスペクトルが混在す る場合には逆重畳法での画像化は原理的に不可能 で，スペクトル情報と空間情報を分離することが必 要となる。このアルゴリズムは既に Eaton らから 報告されていたが，肝心な部分は記載がなく，600 $\mathrm{G} / \mathrm{cm}$ の磁場勾配コイルを自作しながら手探りで研

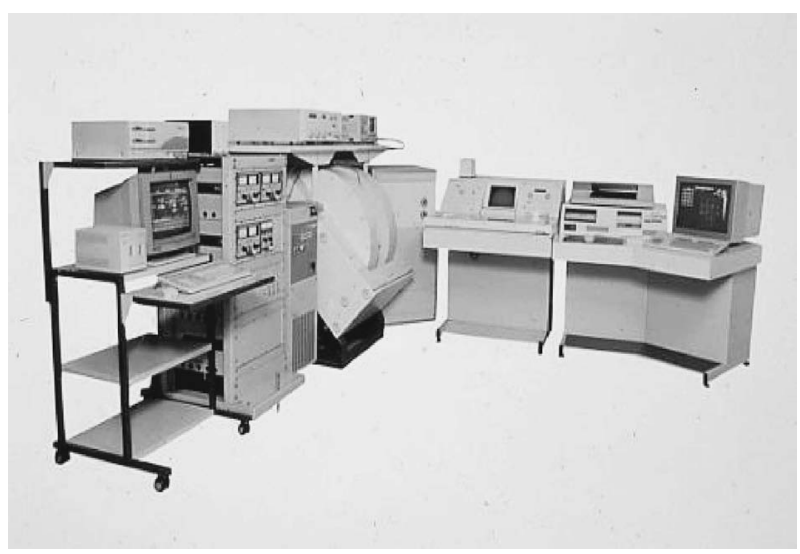

Fig. 3. In Vivo L-band ESRI System Commercialized from JEOL

(a)

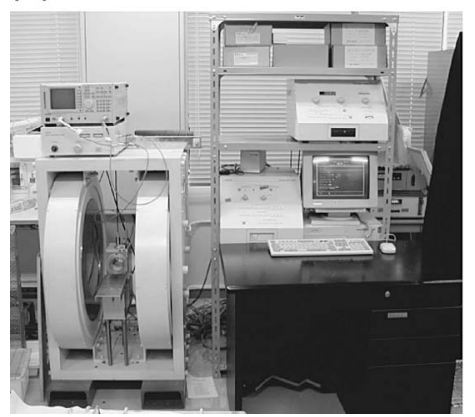

Fig. 4. In Vivo $300 \mathrm{MHz}$ ESR System (a) and Its Resonator (b)
究を開始した。パソコン好きの大学院生と種々の議 論を重ねながらソフトを作成した結果，ヒドロキシ ルラジカル $(\cdot \mathrm{OH})$ と NO をそれぞれ DMPO ない し Fe-MGD 錯体で捕捉後, 両ラジカルの二次元空 間分離画像を得た。 ${ }^{6}$ この方法は，動物体内あるい は組織切片での複数種のラジカル種や drug delivery system（DDS）（薬物輸送担体）の分別可視化を可 能とし, 病態解明や医薬品の解析に強力な手法とな る. 7)

ESRI はラジカルの可視化法として有効な手段で あるが，臓器や組織との対応関係が同定できない. そこで，2000 年に科研費展開研究 A を申請し，日 本電子と日立製作所の協力を得て，ESRI/MRI 融 像可視化装置の試作を行った。診断用 $0.2 \mathrm{~T}$ MRI の中古品を購入し，日本電子が試作した簡易型 ESRI 磁石との間に特注動物移動ベッドを設置した [Fig. 5 (a) ]。また，当時の大学院生が MRI・ESR コイルを試作し，融像画像を得ることに成功した [Fig. 5(b)]. ${ }^{8)}$

マウス体内の油水分配係数の異なる 2 種のプロー ブ, carbamoyl-PROXYL ないし carboxy-PROXYL を静脈内投与（100 mM, $100 \mu \mathrm{L})$ し ESRI/MRI 画 像を得ると，水溶性の carboxy-PROXYL では上腹 部での残留性が高く心臓，肝臓，腎臓に分布する が，微膜浸透性の carbamoyl-PROXYL 投与では, 直後に上腹部全体に分布するものの急速に減少する ことが観察された. ${ }^{91}$

\section{3. 生体計測 ESR を用いた病態モデルでのレド} ックス動態の解析

・OH やスーパーオキシドアニオンラジカル $\left(\cdot \mathrm{O}_{2}^{-}\right)$ など活性酸素の ESR 検出法としてスピントラップ 法が汎用されている。しかし，in vivo ESR 装置 は, 感度が通常の ESR 装置の 1/10-1/100 と低いう えにスピンアダクトが生体内で非常に短寿命である (a)

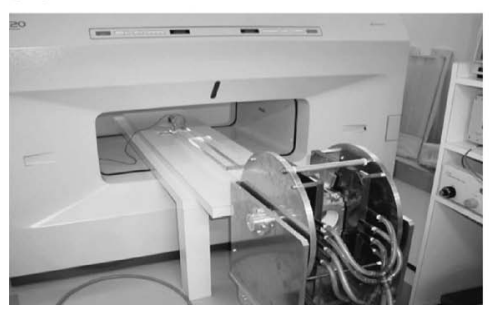

(b)

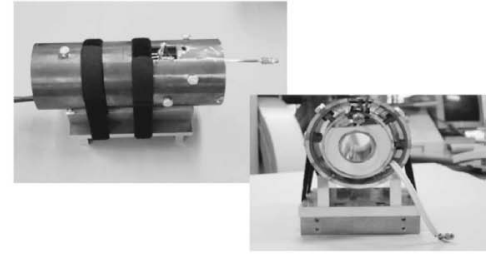

Fig. 5. Fused Imaging System of In Vivo ESRI with MRI (a) and Home-made Dual Resonator for ESRI and MRI (b) 
ため, in vivo ESR 装置で活性酸素を直接検出する ことは困難である。1950 年代の終わりから 1960 年 代の始めにかけて，多種の環状ニトロキシルラジカ ル（以前は「ニトロキシド」と呼んだが，Rozantsev 著“Free Nitroxyl Radicals”に依拠）が合成さ れ, 10) 2,2,5,5-tetramethylpyrrolidine-1-oxyl (PROXYL）誘導体や 2,2,6,6-tetramethylpiperidine-1-oxyl （TEMPO）誘導体など種々のニトロキシルラジカ ルが市販されている，筆者は大学院博士課程でスピ ンラベル法を研究していたが，ニトロキシルラジカ ルが，生体内の種々の酸化還元酵素で容易に還元さ れることが欠点の 1 つであった. ニトロキシルラジ カルと生体内酸化還元酵素や遷移金属との反応につ いて研究され, ${ }^{11)}$ 活性酸素との反応でもシグナルが

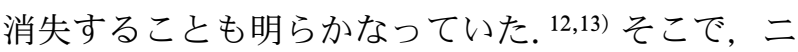
トロキシルラジカルと活性酸素との反応性に着目し 「in vivo $\mathrm{ESR} /$ スピンプローブ法」を作業仮説とし て研究を進めた。この方法は，Fig. 6 に示すよう に，ニトロキシルラジカルをスピンプローブ剤とし て疾患モデル動物の体内に投与し，その ESR シグ ナル強度の変動からレドックス状態を推測するもの で，減衰速度に及ぼす各種抗酸化剂，阻害剂処置の 影響を計測し生体内の活性酸素の生成とそのメカニ

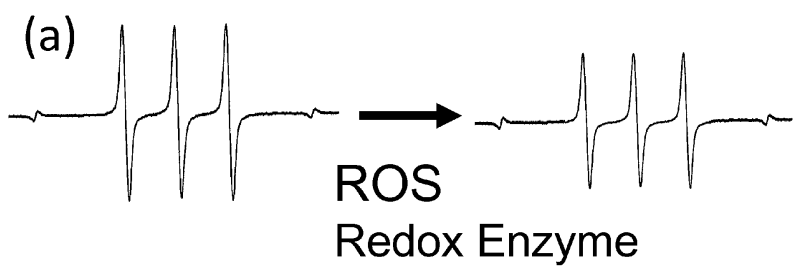

(b)

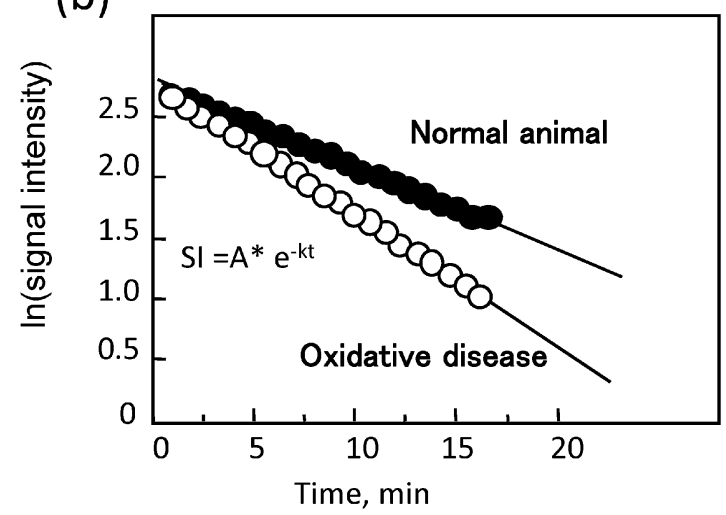

Fig. 6. In Vivo ESR Spectra of Nitroxyl Radical in Mouse after Intra-Venous Injection (a) and Semilogarithmic Plot of In Vivo ESR Signal Intensities with the Period after Injection (b)
ズムを解析する，筆者らは，鉄過剩負荷肝障害, ${ }^{14)}$ ディーゼルエンジン排気ガス惹起肺障害, ${ }^{15)}$ 脳虚血 一再灌流障害, ${ }^{16)}$ 種々の胃潰瘍モデル（アンモニア 惹起, ${ }^{17)}$ 水浸拘束, ${ }^{18)}$ あるいはインドメタシン誘 発 $\left.{ }^{19)}\right)$ ， ストレプトゾトシン惹起糖尿病, ${ }^{20)}$ ポルフ イリン症皮膚障害, ${ }^{21)}$ アジュバンド関節炎, 22$)$ ジエ チルニトロソアミン惹起肝がん, ${ }^{23)}$ 移植がん, ${ }^{24)}$ ドーパミン誘発脳機能障害25,26)など種々の疾患モデ ル動物体内での活性酸素生成あるいはレドックス変 動を in vivo ESR/スピンプローブ法を用いて無侵 襲解析してきた。他の研究グループからは，X 線 照射27) やがん, ${ }^{28)}$ アスベスト肺, ${ }^{29)}$ 糖尿病モデル, ${ }^{30)}$ その他の疾患モデル ${ }^{31-33)}$ などが報告されている. 古 い情報であるが，2008 年までの報告例を PubMed で検索し，その結果を Table 1 に示す. Table 1 中 の＃は上記のシグナル減衰の㠵進を確認したもので ある。この手法は海外で腫瘍部位などでの酸素濃度 計測にも応用されている. ${ }^{40)}$

ニトロキシルラジカルをプローブとする in vivo $\mathrm{ESR} /$ スピンプローブ法の科学的妥当性を実証する には，シグナル減衰速度と活性酸素生成量との関係 を明確にすることが不可欠である，そこで，われわ れは・OH 発生系のフェントン試薬を添加し in vitro ESR シグナル減衰速度を算出・解析した。 次に, carbamoyl-PROXYL の代わりにスピントラップ剂 DMPO を添加し, 生成するスピンアダクト DMPO$\mathrm{OH}$ 生成量への阻害作用を解析したところ，シグナ ル減衰速度と DMPO-OH 生成量との関係は非常に よい相関を示し（ $\mathrm{R}=0.92, p<0.0001)$ ，阻害も認 められた (Fig. 7)。これらから，ニトロキシルラ ジカルの ESR シグナル減衰速度から・OH 生成量を 半定量的に評価できることが明らかとなった. ${ }^{19)}$

Figure 8 に示すように，ニトロキシルプローブに 化学修飾を施すことで細胞内外のレドックス動態を 分離解析できる。 ${ }^{41,42)}$ 例えば, carboxy-PROXYL $(n$-オクタノール/水分配係数 $\mathrm{Po} / \mathrm{w}=0.0047)$ は主 に水系に, MC-PROXYL $(\mathrm{Po} / \mathrm{w}=8.7)$ は膜内に存 在し, carbamoyl-PROXYL $(\mathrm{Po} / \mathrm{w}=0.68)$ はわず かに膜と相互作用する。特に，AMC-PROXYL は 細胞内のカルボキシルエステラーゼにより加水分解 され carboxy-PROXYL に変換することで細胞内に 蓄積する性質を有する. ${ }^{42)}$ 尾静脈内投与後のマウス 頭部における分布画像から AMC-PROXYL は脳質 
Table 1. Reports of Application of In Vivo ESR/Nitroxyl Probe Technique to Animal Models in Diseases

\begin{tabular}{|c|c|c|c|}
\hline Experimental models & Authors & Journal (Year) & Reference \\
\hline Hypoxia & Miura Y. et al. & Biochem Biophys Res Commun (1992) & $(2)^{*, \#}$ \\
\hline IR Injury & Utsumi H. et al. & Free Radic Res Commun (1993) & $(34)^{*, \#}$ \\
\hline X-ray Irradiation & Miura Y. et al. & Free Radic Biol Med (1997) & $(27)^{\#}$ \\
\hline STZ-induced diabetes & Sano T. et al. & Diabetologia (1998) & $(5)^{*, \#}$ \\
\hline RIF-1 Implantation & Kuppusamy P. et al. & Cancer Res（1998） & $(28)^{\#}$ \\
\hline Iron Overload & Phumala N. et al. & Free Radic Biol Med (1999) & $(14)^{*, \#}$ \\
\hline Seizures & Yokoyama H. et al. & Magn Reson Imaging (2000) & $(35)$ \\
\hline Lung Injury (DEP) & Han J. Y. et al. & Free Radic Biol Med (2001) & $(15)^{*, \#}$ \\
\hline Myocardial Infarction & Tsutsui H. et al. & Circulation (2001) & $(31)^{\#}$ \\
\hline Acute Asbestosis & Leonard S. S. et al. & Mol Cell Biochem (2002) & $(32)$ \\
\hline Gastric Ulcer (ammonia) & Kasazaki K. et al. & Free Radic Res (2003) & $(17)^{*, \#}$ \\
\hline MCAO & Yamato M. et al. & Free Radic Biol Med (2003) & $(16)^{*, \#}$ \\
\hline Diabetes (STZ) & Matsumoto S. et al. & Free Radic Res (2003) & $(20)^{*, \#}$ \\
\hline TNBS-induced Colitis & Togashi H. et al. & Gut (2003) & (33) \\
\hline Gastric Ulcer (Stress) & Yasukawa K. et al. & Free Radic Res (2004) & $(18)^{*, \#}$ \\
\hline Protoporphyria & Takeshita K. et al. & J Invest Dermatol (2004) & $(21)^{*, \#}$ \\
\hline Obesity & Sonta T. et al. & Free Radic Biol Med (2004) & $(30)^{\#}$ \\
\hline STZ-induced Diabetes & Tsubouchi H. et al. & Free Radic Biol Med (2005) & $(36)^{\#}$ \\
\hline Lung Injury & Kaimul Ahsan M. et al. & Free Radic Biol Med (2005) & $(37)^{\#}$ \\
\hline Gastric Ulcer (NSAIDs) & Utsumi H. et al. & J Pharmacol Ther Exp (2006) & $(19) *, \#$ \\
\hline Adjuvant Arthritis & Yamada K. et al. & Free Radic Res（2006） & $(22) *, \#$ \\
\hline Liver Injury（DEN） & Yamada K. et al. & Free Radic Biol Med (2006) & $(23)^{*, \#}$ \\
\hline UV-induced Skin Injury & Takeshita K. et al. & Free Radic Biol Med (2006) & $(38)^{\#}$ \\
\hline Diabetic Eye & Yamato M. et al. & Antioxid Redox Signal (2007) & $(26)^{\#}$ \\
\hline Tumor in Foodpat & Ichikawa K. et al. & Antioxid Redox Signal (2007) & $(24) *, \#$ \\
\hline Myocardial Infarction & Tsutsumi T. et al. & Cardiovasc Res (2008) & $(39)^{\#}$ \\
\hline
\end{tabular}

* Represents the reference reported by our group, and * shows the case in which the enhanced signal decay was observed.

(a)

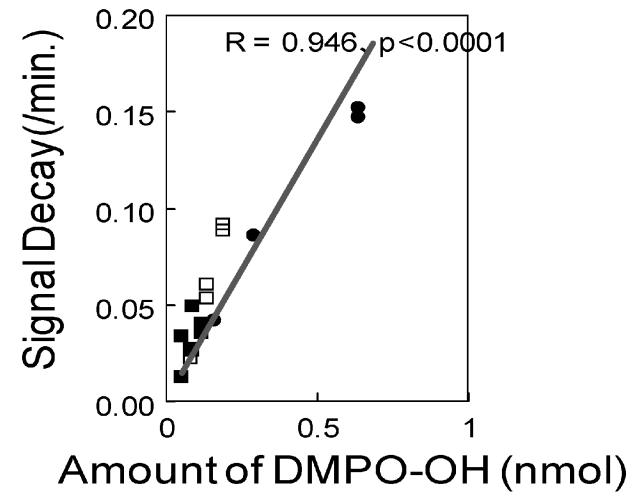

(b)

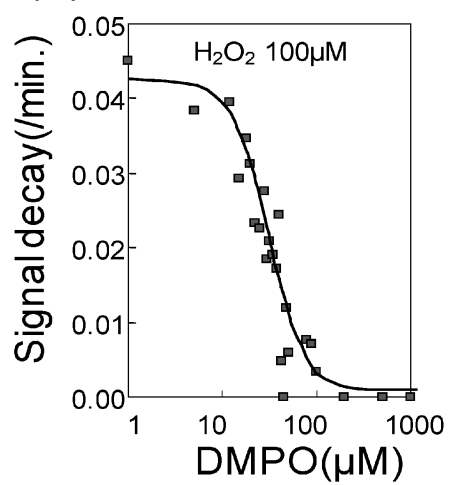

Fig. 7. Relation of $\cdot \mathrm{OH}$ Generation, Spin-Adduct of DMPO-OH and the Signal Decay Rate of Nitroxyl Probe (a) and Inhibition Assay of Its Signal Decay Rate with Spin-Trapping Reagent DMPO (b)

部分に高濃度で滞留し, 種々の脳疾患における活性 酸素動態の解析に有効であることが示され，種々の プローブ剤を組み合わせることで活性酸素動態を細 胞膜内外で解析できる.
さらに，ニトロキシルラジカルの置換基を修飾す ることで活性酸素や抗酸化剂への感受性が異なるプ ローブも得られており, ${ }^{43,44)}$ 今後多くの酸化ストレ ス疾患での局所活性酸素動態・レドックス状態が解 


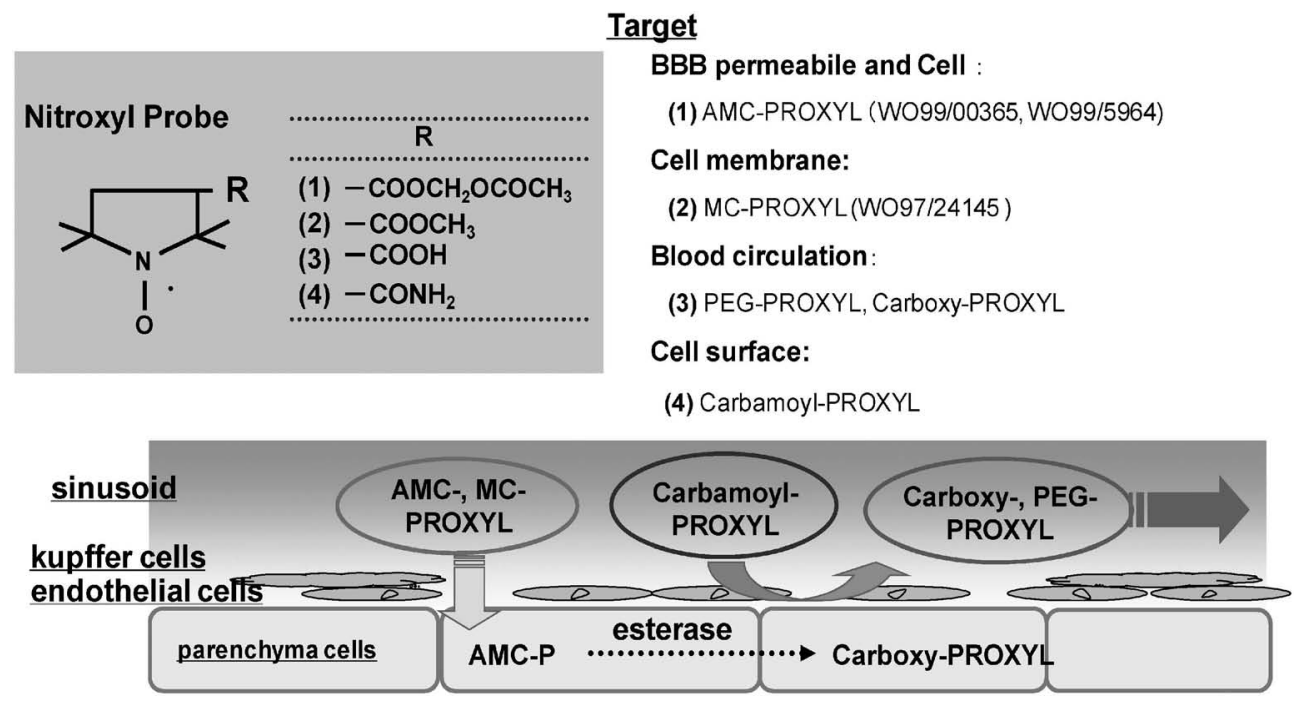

Fig. 8. Development of Site-targetted Nitoroxyl Probes and Their Pharmacokinetic Properties in Blood Vessel

明できるものと期待している.

\section{4. 新たなレドックス画像化システム ReMI（Re-} dox Molecular Imaging)

「オーバーハウザー効果」とは, Fig. 9 に示すよう に，フリーラジカルの電子スピンを ESR 遷移させ, 電子スピンと核スピンの双極子相互作用により核ス ピンが偏極 (dynamic nuclear polarization; DNP) する現象である. ${ }^{45)}$ 熱平衡状態では，基底状態と励 起状態にある核スピンの比はボルツマン分布に従 い，例えば磁場が $0.4 \mathrm{~T}$ でのゼーマン分裂では，全 部の核スピンが 1000000 個あるとすると，励起状 態の核スピンと基底状態の核スピンの差はわずか 1.3 個にすぎない。，一方，電子スピンの磁気回転比 はプロトンに比べ 654 ほど大きく両状態間のスピン 数の差は $1.3 \times 654$ となり, DNP により核スピンの ボルツマン分布が最大（理論值）で 330 倍に増強さ れる。したがって，DNP を MRI に応用すると通 常の MRI 測定に比べ 330 倍（理論值）の高感度化 を図ることができる，Lurie らはこのオーバーハウ ザー効果に着目しフリーラジカルの画像化装置,

DNP-MRI を開発した. ${ }^{46)}$ ESRI は ESR シグナルの 緩和時間が非常に短いため MRI に比べると空間分 解能・時間分解能が著しく低い。DNP-MRI はラジ カルの ESR 励起により偏極した水プロトンを MRI で可視化することで，高い空間分解能を持ち，短時 間測定が可能である.オランダの Philips 社はこの 有用性に着目し，造影剤メーカーである Nycomed 社 (Sweden) と協力して DNP-MRI 開発に着手し,

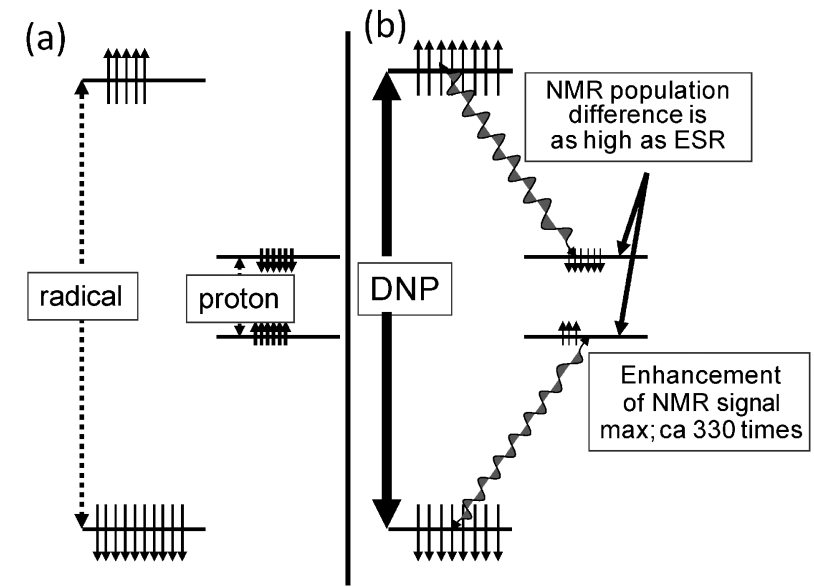

Fig. 9. Boltzman Distribution of Electron Spin and Proton (a), and Dynamic Nuclear Polarization (DNP; Overhauser Effect) (b)

1998 年にプロトタイプ 1 号機を完成した. しかし， MRI 磁場強度が $0.015 \mathrm{~T}$ と低いために十分な感度 が得られず，現在，開発は中断している，GE 社は DNPI に高い関心を示し Nycomed を買収すること で基本特許を取得し，生体外で DNP したプローブ を担がんマウスに投与し代謝画像を得る方法を開発 し新たな画像化法として世界戦略しつつある。

筆者は 1999 年に Philips の MRI 研究所を訪ねる 機会を得，2001 年から DNP-MRI 装置の試作を検 討した. Philips と Nycomed は DNP-MRI をがん組 織の酸素濃度組織の可視化診断装置としての展開を 考え，いくつかの研究室でも動物実験に成功してい た. ${ }^{47,48)}$ 九州大学で大型装置の予算がつき, 結果と 
して試作を待つことなく Philips 社の R\&D を導入 することとした，導入に当たり，Philips の MRI 研 究所を再度訪ね，新たな分離画像化アルゴリズムを 提案した。 ${ }^{14} \mathrm{~N},{ }^{15} \mathrm{~N}$ 標識ニトロキシルラジカルは, ESR スペクトルの共鳴磁場が異なる，そこで，Fig. 10 に示すように, ESR 励起を ${ }^{14} \mathrm{~N},{ }^{15} \mathrm{~N}$ の核種で交 互に行えば，複数のプローブが同時に画像化できる

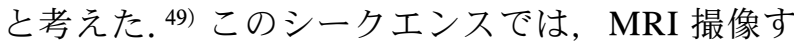
る際に各位相エンコード毎に ${ }^{14} \mathrm{~N},{ }^{15} \mathrm{~N}$ を交互に ESR 励起することから， ${ }^{14} \mathrm{~N},{ }^{15} \mathrm{~N}$ を同時分離した可 視化が可能である。このパルスシークエンスを用い て，酸化反応と還元反応を同時に画像化できるかど

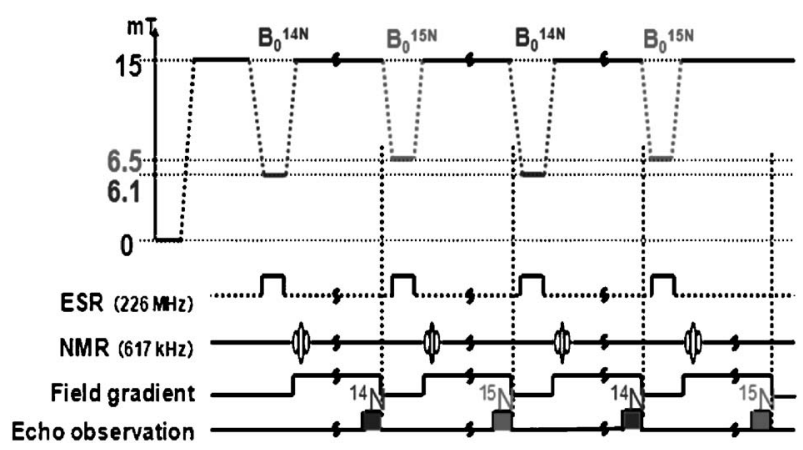

Fig. 10. Novel Sequence for Serapative DNP-MRI System
うかを検討した．Figure 11 に示すように，3 本の 試験管には左から順に 20,10,5 mM のアスコルビ ン酸（ascorbic acid; ASA）と ${ }^{15} \mathrm{~N}$ で標識した carbamoyl-PROXYL を封入し，他の 3 本の試験管に は，左から順に $1.2,0.8,0.4 \mathrm{U} / \mathrm{mL}$ のヒドロペルオ キシダーゼ (hydroperoxidase; HRP) と $\mathrm{H}_{2} \mathrm{O}_{2},{ }^{14} \mathrm{~N}$ で標識したヒドロキシルアミン体を封入し，DNPMRI 同時分離画像を経時的に取得した。ニトロキ シルラジカルは，ASA の濃度依存的に画像強度が 減少し，ヒドロキシルアミン体は HRP の濃度依存 的に画像強度が増加する様子を明瞭に示された。 ま た，Fig. 12 に示すように，非膜透過性の ${ }^{15} \mathrm{~N}-\mathrm{car}-$ boxy-PROXYL と膜透過性の ${ }^{14} \mathrm{~N}-\mathrm{MC}-\mathrm{PROXYL}$ を アスコルビン酸封入リポソームと混合し同時分離画 像すると，膜透過性 MC-PROXYL ではリポソーム 内のアスコルビン酸との反応で顕著に輝度が減少す るのに対し，非膜透過性 carboxy-PROXYL では輝 度が全く変化しない画像が得られ，厚さ $8 \mathrm{~nm}$ のリ ポソーム膜を隔てた内側と外側でのレドックス動態 を分離して同時に視覚化できることが示された。ま た，感度を向上させる表面コイルを作製し, ${ }^{50)}$ 膜透 過性のプローブを用いて脳梗塞モデルで可視化する と，梗塞巣で明らかなレドックス代謝機能障害が認
A)

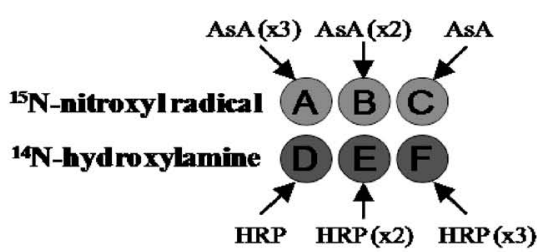

C)

Reduction Image

$\left({ }^{15} \mathrm{~N}-\mathrm{form}\right)$

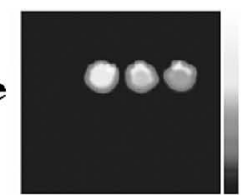

Oxidation Image $\left({ }^{14} \mathrm{~N}-\right.$ form)

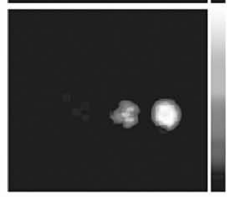

B)

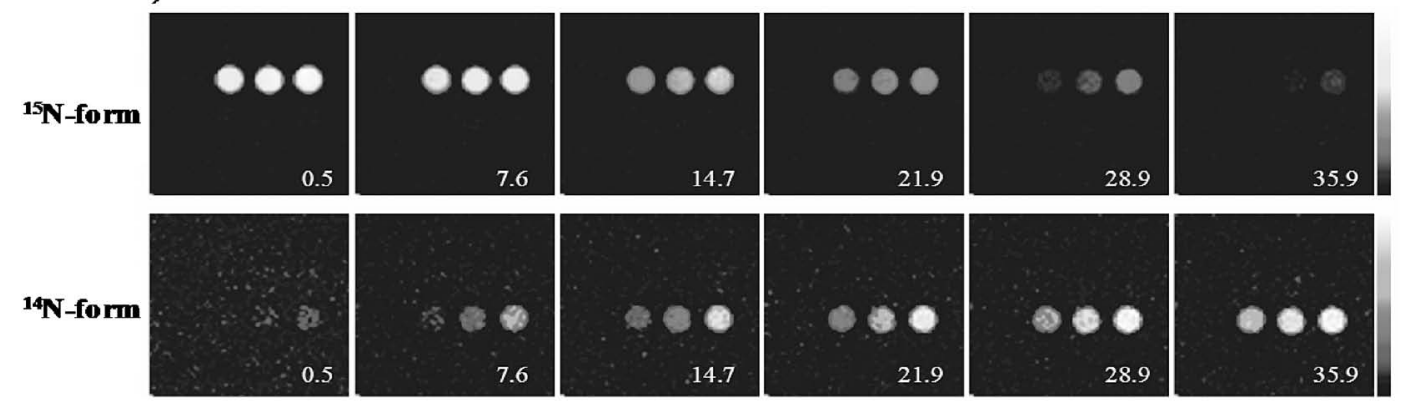

A: $20 \mathrm{mM}$ AsA, B: $10 \mathrm{mM}$ AsA, C:5 mM AsA: (A, B, C: $2 \mathrm{mM}{ }^{15} \mathrm{~N}$ carbamoyl-PROXYL)

D:1.2 U/mL HRP, E: 0.8 U/mL HRP, F: $0.4 \mathrm{U} / \mathrm{mL}$ HRP, (D,E,F: $5 \mathrm{mM}{ }^{14} \mathrm{~N}$ carbamoyl-PROXYL hydroxylamine, $5 \mathrm{mM} \mathrm{H}_{2} \mathrm{O}_{2}$ )

Fig. 11. Separative Imaging of Redox Reaction with DNP-MRI

(a) Phantom of reduction of ${ }^{15} \mathrm{~N}$-nitroxyl radical and oxidation of its ${ }^{14} \mathrm{~N}$-hydroxylamine. (b) Time-dependent DNP-MRI images of ${ }^{15} \mathrm{~N}$-nitroxyl radical and ${ }^{14} \mathrm{~N}$-hydroxylamine. (c) Simultaneous redox rate imaging. 


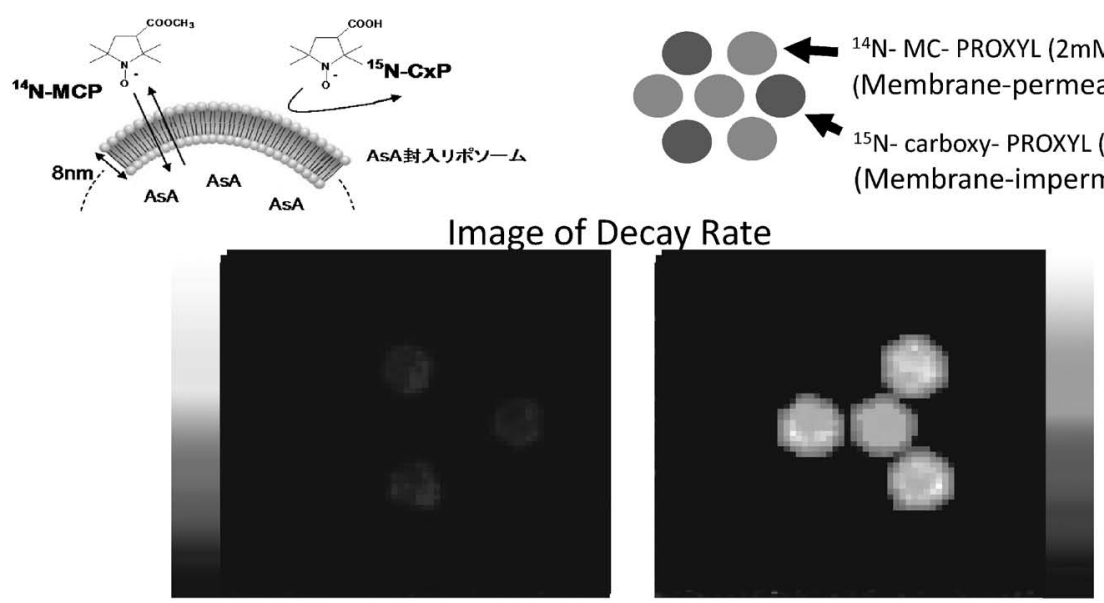

Fig. 12. Separative Imaging of Site-Specfic Reaction with DNP-MRI

Phantom consisted of ascorbic acid encupsulating liposomes and membrane-impermeable ${ }^{15} \mathrm{~N}$-carboxyl-PROXYL ( 3 tubes, black) or membrane-permeable ${ }^{14} \mathrm{~N}-M C-P R O X Y L$ (4 tubes, light dark), and their simultaneous redox rate imaging.

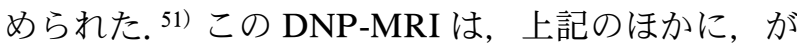
ん組織の酸素動態，血管壁透過性の画像解析 ${ }^{52}$ や脂 質膜内でのレドックス動態, ${ }^{53)}$ 個体全体でのレドッ クス応答分子の動態画像解析 $(\mathrm{PK} / \mathrm{PD} \text { 可視化 })^{54)}$ などでも極めて有効であることが示されている．ま た，質量分析画像化と組み合わせることで分子の変 化量とも関連づけることができる. ${ }^{55)}$ 特許の関係で 詳細を記述できないが，既に合成物質を用いない可 視化法も見い出しておりヒトへの応用が近未来で可 能である. 次項に述べる高感度装置の開発を含め, 新規の画像化法としての Redox Molecular Imaging, ReMI を提案し，ヒトへの応用を進めている.

\section{5. 高磁場 ReMI の開発}

MRI の感度は外部磁場強度に大きく依存し，2-3 乗で感度が増大することから，世界的には 5-10 T の高磁場装置が開発途上で，3 T の臨床装置が市販 されている状況であり，わが国の MRI 装置は最近 では欧米の後塵を配している。生体計測において ESR の電磁波は生体浸透性がよい $600 \mathrm{MHz}$ 以下に 限定され，結果として ESR 共鳴磁場は $20 \mathrm{mT}$ 以下 となり MRIの外部磁場も同程度となる。事実,

Phillips 社の MRI 磁場は $15 \mathrm{mT}$ で診断機器として 十分な感度が得られず，開発中断に至った。そこ で，われわれは 2004 年から 5 年間，独科学技術振 興機構の先端計測分析技術・機器開発事業の支援を 受け，高磁場 ReMI の開発を進めた。 日本電子，富 士電機，日立メディコ，ネオマックスと共同で MRI 磁場を $1 \mathrm{~T}$ 以上，ESR 磁場を $20 \mathrm{mT}$ とし両磁
場間で実験動物を移動することで高感度化を図っ た. 当初は試料を ESR・MRI 磁石間で往復移動さ せ， ReMI 撮像に成功した．さらにこの方法では加 速度が大きく動物への負荷が大きいことから，新た に円移動用に両磁石を開発するとともに新たなアル ゴリズムを検討した結果，磁気共鳴の常識では全く 想像外の「等速円移動 MRI」法を発見した。. $56-58$ ) この装置は Fig. 13 に示すように，実験動物を等速 回転させ， $20 \mathrm{mT} ・ \mathrm{ESR}$ 磁場で $500 \mathrm{~ms}$ の DNP を 行い $100 \mathrm{~ms}$ 後に $1.5 \mathrm{~T}$ ・MRI で撮像する方法で, 外径 $1 \mathrm{~mm}$ のキャピラリー（厚さ $0.1 \mathrm{~mm}$ ）に封入 した 0.2-2 mM のラジカルが明確に可視化できてい る. また，マウス小腸に投与したラジカルも小腸が 輪切りとなって可視化され，MRI 画像も非常に明 瞭で, レドックス・臟器像の融像化が可能となつ た。今後は，新規ヒト診断装置に向け，要素開発の 基礎研究を進めることでわが国初の革新的医療機器 を目指したい．

6. おわりに

以上，in vivo ESR 画像化装置の開発，ニトロキ シルプローブ法の確立, 病態モデルでのフリーラジ カル動態の無侵襲解析，機能性プローブの合成・応 用， ESRI/MRI 融像システムの開発及び，DNPMRI を用いた分子イメージング研究について概説 するとともに新たに新規レドックス分子画像化装 置・解析法 ReMI を提案した。 今後, 生体磁気共鳴 画像システムの高感度化，高解像度化がさらに進む につれ，疾患モデルにおける生体レドックス動態の 
(a)

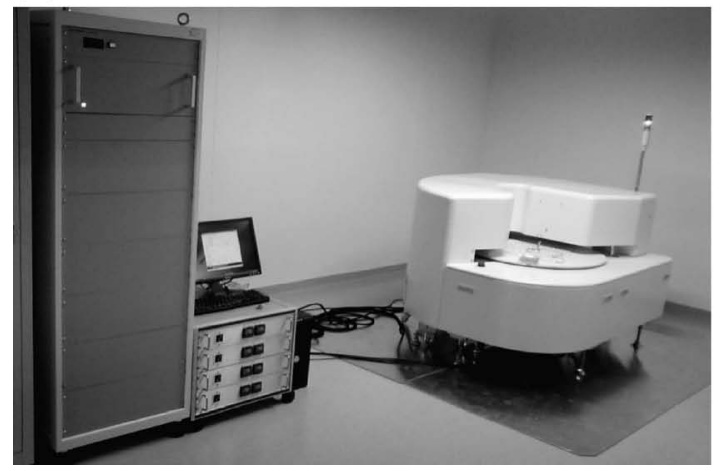

(b)

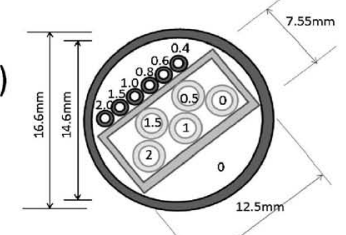

MRI

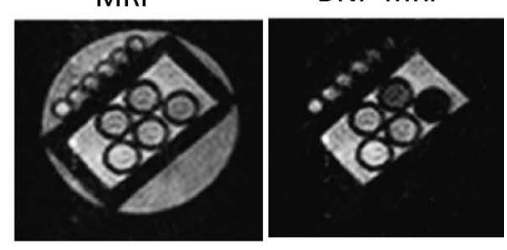

Fig. 13. (a) Development of $1.5 \mathrm{~T}$ High Sensitive DNP-MRI, (b) Phantom Consisted of 6 Cappilaries and 5 Tubes in Micro-UV Cell, and Images of MRI and DNP-MRI

詳細が明らかになり，画期的な画像診断法へ発展す るものと期待される.

\section{謝辞本研究は昭和大学薬学部衛生化学教室並} びに九州大学大学院薬学研究院機能分子解析学教室 (旧薬品物理化学教室), 九州大学先端融合医療レド ックスナビ研究拠点で行われたものである，一緒に 研究に尽力して頂いた職員・学生の諸氏に心から感 謝申し上げます。

\section{REFERENCES}

1) Utsumi H., Muto E., Masuda S., Hamada A., Biochem. Biophys. Res. Commun., 172, 13421348 (1990).

2) Miura Y., Utsumi H., Hamada A., Biochem. Biophys. Res. Commun., 182, 1108-1114 (1992).

3) Gomi F., Utsumi H., Hamada A., Life Sci., 52, 2027-2033 (1993).

4) Takeshita K., Utsumi H., Hamada A., Biochem. Biophys. Res. Commun., 177, 874-880 (1991).

5) Sano T., Umeda F., Hashimoto T., Nawata H., Utsumi H., Diabetologia, 41, 1355-1360 (1998) .

6) Matsumoto K., Utsumi H., Biophys. J., 79, 3341-3349 (2000).

7) Matsumoto K., Yahiro T., Yamada K., Utsumi H., Magn. Reson. Med., 53, 1158-1165 (2005).

8) Matsumoto S., Nagai M., Yamada K., Hyodo
F., Yasukawa K., Muraoka M., Hirata H., Ono M., Utsumi H., Concepts Magn. Reson. Part B, 25B, 1-11 (2005).

9) Hyodo F., Yasukawa K., Yamada K., Utsumi H., Magn. Reson. Med., 56, 938-943 (2006).

10) Rozantsev E. G., "Free Nitroxyl Radicals, Synthesis of some stable radicals and the most important intermediates," ed. by Ulrich H., Plenum Press, New York, 1970, pp. 203-246.

11) Kocherginsky N., Swartz H. M., "Nitroxide Spin Labels: Reactions in Biology and Chemistry, Chemical reactivity of nitroxides," CRC Press, New York, 1995, pp. 27-66.

12) Asmus K. D., Nigam S., Willson R. L., Int. J. Radiat. Biol., 29, 211-219 (1976).

13) Finkelstein E. M., Rosen G. M., Rauckman E. J., Biochim. Biophys. Acta, 802, 90-98 (1984).

14) Phumala N., Ide T., Utsumi H., Free Radic. Biol. Med., 26, 1209-1217 (1999).

15) Han J. Y., Takeshita K., Utsumi H., Free Radic. Biol. Med., 30, 516-525 (2001).

16) Yamato M., Egashira T., Utsumi H., Free Radic. Biol. Med., 35, 1619-1631 (2003).

17) Kasazaki K., Yasukawa K., Sano H., Utsumi H., Free Radic. Res., 37, 757-766 (2003).

18) Yasukawa K., Kasazaki K., Hyodo F., Utsumi H., Free Radic. Res., 38, 147-155 (2004).

19) Utsumi H., Yasukawa K., Soeda T., Yamada K., Shigemi R., Yao T., Tsuneyoshi M., J. Pharmacol. Exp. Ther., 317, 228-235 (2006) .

20) Matsumoto S., Koshiishi I., Inoguchi T., Nawata H., Utsumi H., Free Radic. Res., 37, 
767-772 (2003).

21) Takeshita K., Takajo T., Hirata H., Ono M., Utsumi H., J. Invest. Dermatol., 122, 14631470 (2004).

22) Yamada K. I., Nakamura T., Utsumi H., Free Radic. Res., 40, 455-460 (2006).

23) Yamada K., Yamamiya I., Utsumi H., Free Radic. Biol. Med., 40, 2040-2046 (2006) .

24) Ichikawa K., Sakabe E., Kuninobu K., Yamori T., Tsuruo T., Yao T., Tsuneyoshi M., Utsumi H., Antioxid. Redox Signal., 9, 1699-1707 (2007).

25) Yamato M., Kudo W., Shiba T., Yamada K. I., Watanabe T., Utsumi H., Free Radic. Res., 44, 249-257 (2010).

26) Yamato M., Matsumoto S., Ura K., Yamada K. I., Naganuma T., Inoguchi T., Watanabe T., Utsumi H., Antioxid. Redox Signal., 9, 367-373 (2007).

27) Miura Y., Anzai K., Urano S., Ozawa T., Free Radic. Biol. Med., 23, 533-540 (1997).

28) Kuppusamy P., Afeworki M., Shankar R. A., Coffin D., Krishna M. C., Hahn S. M., Mitchell J. B., Zweier J. L., Cancer Res., 58, 15621568 (1998).

29) Yokoyama H., Lin Y., Itoh O., Ueda Y., Nakajima A., Ogata T., Sato T., Ohya-Nishiguchi H., Kamada H., Free Radic. Biol. Med., 27, 442-448 (1999).

30) Sonta T., Inoguchi T., Tsubouchi H., Sekiguchi N., Kobayashi K., Matsumoto S., Utsumi H., Nawata H., Free Radic. Biol. Med., 37, 115-123 (2004).

31) Tsutsui H., Ide T., Hayashidani S., Suematsu N., Shiomi T., Wen J., Nakamura K., Ichikawa K., Utsumi H., Takeshita A., Circulation, 104, 134-136 (2001).

32) Leonard S. S., Mowrey K., Pack D., Shi X., Castranova V., Kuppusamy P., Vallyathan V., Mol. Cell. Biochem., 234-235, 369-377 (2002).

33) Togashi H., Oikawa K., Adachi T., Sugahara K., Ito J., Takeda T., Watanabe H., Saito K., Saito T., Fukui T., Takeda H., Ohya H., Kawata S., Gut, 52, 1291-1296 (2003) .

34) Utsumi H., Takeshita K., Miura Y., Masuda S., Hamada A., Free Radic. Res. Commun., 19 (Suppl. 1), S219-S225 (1993).

35) Yokoyama H., Itoh O., Aoyama M., Obara
H., Ohya H., Kamada H., Magn. Reson. Imaging, 18, 875-879 (2000) .

36) Tsubouchi H., Inoguchi T., Sonta T., Sato N., Sekiguchi N., Kobayashi K., Sumimoto H., Utsumi H., Nawata H., Free Radic. Biol. Med., 39, 444-452 (2005).

37) Kaimul Ahsan M., Nakamura H., Tanito M., Yamada K., Utsumi H., Yodoi J., Free Radic. Biol. Med., 39, 1549-1559 (2005).

38) Takeshita K., Chi C., Hirata H., Ono M., Ozawa T., Free Radic. Biol. Med., 40, 876885 (2006).

39) Tsutsumi T., Ide T., Yamato M., Kudou W., Andou M., Hirooka Y., Utsumi H., Tsutsui H., Sunagawa K., Cardiovasc. Res., 77, 713721 (2008).

40) Yasukawa K., Kasazaki K., Hyodo F., Utsumi H., "Methods in Redox Signaling," ed. by Das D. K., Mary Ann Liebert, New Rochelle, 2009, pp. 90-99.

41) Sano H., Matsumoto K., Utsumi H., Biochem. Mol. Biol. Int., 42, 641-647 (1997).

42) Sano H., Naruse M., Matsumoto K., Oi T., Utsumi H., Free Radic. Biol. Med., 28, 959969 (2000).

43) Kinoshita Y., Yamada K., Yamasaki T., Sadasue H., Sakai K., Utsumi H., Free Radic. Res., 43, 565-571 (2009).

44) Kinoshita Y., Yamada K., Yamasaki T., Mito F., Yamato M., Kosem N., Deguchi H., Shirahama C., Ito Y., Kitagawa K., Okukado N., Sakai K., Utsumi H., Free. Radic. Biol. Med., 49, 1703-1709 (2010).

45) Overhauser A. W., Phys. Rev., 92, 411-412 (1953).

46) Lurie D. J., Bussell D. M., Bell L. H., Mallard J. R., J. Magn. Reson., 76, 366-370 (1988) .

47) Li H., Deng Y., He G., Kuppusamy P., Lurie D. J., Zweier J. L., Magn. Reson. Med., 48, 530-534 (2002).

48) Krishna M. C., English S., Yamada K., Yoo J., Murugesan R., Devasahayam N., Cook J. A., Golman K., Ardenkjaer-Larsen J. H., Subramanian S., Mitchell J. B., Proc. Natl. Acad. Sci. USA, 99, 2216-2221 (2002).

49) Utsumi H., Yamada K., Ichikawa K., Sakai K., Kinoshita Y., Matsumoto S., Nagai M., Proc. Natl. Acad. Sci. USA, 103, 1463-1468 (2006). 
50) Matsumoto S., Yamada K., Hirata H., Yasukawa K., Hyodo F., Ichikawa K., Utsumi H., Magn. Reson. Med., 57, 806-811 (2007).

51) Yamato M., Shiba T., Yamada K., Watanabe T., Utsumi H., J. Cereb. Blood Flow Metab., 29, 1655-1664 (2009).

52) Matsumoto S., Yasui H., Batra S., Kinoshita Y., Bernardo M., Munasinghe J. P., Utsumi H., Choudhuri R., Devasahayam N., Subramanian S., Mitchell J. B., Krishna M. C., Proc. Natl. Acad. Sci. USA, 106, 17898-17903 (2009).

53) Benial A. M., Utsumi H., Ichikawa K., Murugesan R., Yamada K., Kinoshita Y., Naganuma T., Kato M., J. Magn. Reson., 204, 131-
138 (2010).

54) Kosem N., Naganuma T., Ichikawa K., Phumala Morales N., Yasukawa K., Hyodo F., Yamada K., Utsumi H., Free Radic. Biol. Med., 53, 328-336 (2012).

55) Miura D., Fujimura Y., Yamato M., Hyodo F., Utsumi H., Tachibana H., Wariishi H., Anal. Chem., 82, 9789-9796 (2010).

56) Ichikawa K., Utsumi H., WO Patent 2010004427A3 (2010).

57) Ichikawa K., Takahashi T., Utsumi H., U.S. Patent 201200068705A1 (2012).

58) Ichikawa K., Takahashi T., Utsumi H., EP Patent 2412309A1 (2012). 